\title{
POTENTIAL USE OF SPRING BUDDING TECHNIQUES IN PRODUCTION OF PLUM NURSERY TREES
}

\author{
Jan Wolf\#, Ivo Ondrášek, and Tomáš Nečas \\ Faculty of Horticulture, Mendel University, Valticki 337, Lednice, 69144, CZECH REPUBLIC \\ \# Corresponding author, jan.wolf@mendelu.cz
}

Communicated by Dainis Ruṇgis

\begin{abstract}
The main objective of this work was to verify the possibility of shortening the time needed to produce nursery trees of plums, in view of the economic profitability in nursery production. To achieve this goal, rootstocks Citation $^{\circledR}$, Ishtara ${ }^{\circledR}$, Penta $^{\circledR},{ }^{\circledR}$, Torine ${ }^{\circledR}$, Pumiselekt and St. Julien (from Wädenswil) were chip budded in the springtime with 'Shiro', 'Angeleno ${ }^{\circledR}$, 'Black Amber', SLE2014/1, 'Fertility' (Asian type plums) and 'Stanley' (European type plum) as a control. At the end of the vegetation period, height (from the grafting position), trunk diameter above the place of budding and the number of shoots was recorded for each tree. The Penta ${ }^{\circledR}$ rootstock was evaluated as the most efficient, while 'Shiro' variety was evaluated as the most suitable variety. The best variety/rootstock combination was the combination of 'Shiro' on Ishtara ${ }^{\circledR}$ rootstock, where $100 \%$ of the budded trees reached an average height of $33.0 \pm 3.6 \mathrm{~cm}$. The highest trees of an average of $68.3 \pm 4.6 \mathrm{~cm}$ were recorded for the combination of SLE2014/1 on Torine ${ }^{\circledR}{ }^{\text {root- }}$ stock.
\end{abstract}

Key words: chip budding, Asian plums, European plums, rootstocks, fruit nursery.

\section{INTRODUCTION}

Currently, the most commercially grown plum trees belong to the Asian (diploid) or the European (mostly hexaploid) type of plums. The Asian plums, also called Japanese plums, were derived originally from Prunus salicina Lindl. Yet, at present, the name Japanese plum is being used for all plum varieties arising from cross breeding of various diploid species of the Rosaceae family with Prunus salicina Lindl. The term "European plum" is nowadays being used for varieties derived from Prunus domestica L. and Prunus cerasifera Ehrh species (Okie and Ramming, 1999).

Budding is the most common method of fruit tree propagation (Kumar, 2011), of which chip budding and T-budding are most used. Both techniques are simple and very fast (Kidd, 1987; Osborne, 1987 and Tubesing, 1988). Tbudding is a good choice for areas with a long vegetation period, since it can only be performed in a limited time span, when the bark lifts off to allow bud insertion (Eiseman and Thomas, 1987). Chip budding on the other hand allows a longer period for budding execution, as it does not require the bark to slip and can therefore be performed in cooler regions too (such as the Great Britain, Howard,
1977). In the Northern Hemisphere, budding is usually done in two main periods throughout the year — in spring from March to May (spring budding) and in summer from July to September (summer budding). In the Czech Republic, summer budding is more common while spring budding is only used for corrective budding in cases, when the summer budded buds fail to grow.

To execute spring budding, the nursery has to prepare dormant buds, which are collected in December and January and properly stored at the temperature of $-2{ }^{\circ} \mathrm{C}$ to $0{ }^{\circ} \mathrm{C}$. In spring mainly chip budding is being performed. Unfortunately, spring budded trees may not always reach the requested strength and height as achieved by summer budded trees. In some nurseries in California and Oregon, USA, spring budding is used with the aim to shorten the time necessary to bring the nursery plant to its final commercial condition and thus to lower the costs of the plant. Rootstocks are planted in the autumn or early spring and budded with desired varieties, usually in April, when the rootstocks start to sprout. Consequently, at the end of the vegetation period one-year old nursery trees are ready for sale. The trees are smaller, yet in this way, the nursery can react faster to mar- 
ket demands, fulfill the orders faster and thus improve the own cash flow. The abovementioned propagation method is predominantly used for stone fruit trees such as peaches, apricots and plums. (Anonymus, 2018)

In the Czech Republic, plum nursery trees are after apple trees the second most frequently produced fruit trees. In 2015, 368269 young plum trees were produced (1 538,000 apple trees) (Buchtová, 2017). Since the 2013/2014 season, when the cost of plum nursery trees in the Czech Republic varied from 2.32 to $4.45 €$, the prices increased to $2.51-4.83 €(2016 / 2017$ season). The wide range of the price is a result of bud/rootstock license fees and nursery tree quality. The main reasons leading to higher prices of nursery trees are increase of labour costs and a labour shortage in the Czech Republic (Kozderová, 2017).

The main goal of the research was to test the method of spring budding in the conditions of the middle Europe to shorten the time for production of nursery trees of Japanese and European plums.

\section{MATERIAL AND METHODS}

Attributes of the location. The study was carried out at the experimental nursery of the Department of Fruit Growing, located at the Faculty of Horticulture of the MENDELU University in the Lednice area. The Lednice area $\left(48^{\circ} 47^{\prime} 59^{\prime \prime} \mathrm{N} 16^{\circ} 48^{\prime} 12^{\prime \prime}\right.$ ?) is situated in the south Moravian region at an altitude of 170 meters above sea level. It is one of the warmest regions in the Czech Republic with an average year temperature of $9.1{ }^{\circ} \mathrm{C}$ and an average rainfall of $422 \mathrm{~mm}$ (Meteorological station located at the Faculty of Horticulture, MENDELU in Brno) (Table 1).

Rootstock. In March (28.03.2017), vegetatively propagated stone fruit rootstocks Citation ${ }^{\circledR}$ Zaipime, Ishtara ${ }^{\circledR}$ Ferciana, St. Julien Hybrid No. 2, Torinel ${ }^{\circledR}$ Avifel, Penta ${ }^{\circledR}$ and Pumiselekt were planted in the experimental nursery.

Table 1 AVERAGE TEMPERATURE AND RAINFALL DATA DURING THE EXPERIMENT (2017)

\begin{tabular}{l|c|c}
\hline \multicolumn{1}{c|}{ Month } & $\begin{array}{c}\text { Average temperature, } \\
{ }^{\circ} \mathrm{C}\end{array}$ & $\begin{array}{c}\text { Rainfall, } \\
\mathrm{mm}\end{array}$ \\
\hline January & -5.0 & 12.0 \\
February & 1.8 & 10.9 \\
March & 8.3 & 20.6 \\
April & 9.6 & 33.7 \\
May & 16.4 & 24.4 \\
June & 21.3 & 51.4 \\
July & 21.5 & 71.7 \\
August & 21.7 & 23.3 \\
September & 14.2 & 71.1 \\
October & 10.9 & 34.8 \\
November & 5.2 & 24.2 \\
December & 2.3 & 18.1 \\
Total & 10.7 & 396.2
\end{tabular}

Rootstocks diameters were from 1 to $2 \mathrm{~cm}$. After planting the rootstocks were irrigated intensively using drum irrigation machinery three times monthly.

Scions. Varieties 'Shiro', 'Angeleno, ${ }^{\circledR}$, 'Black Amber', SLE2014/1, and 'Fertility' (Asian type plums) and 'Stanley' (European type plum) as a reference variety were selected for budding. The scions were collected in January. Scions were stored wrapped in moist paper in a refrigerator at $0{ }^{\circ} \mathrm{C}$ until the conditions were favourable for budding.

Budding and follow-up care. Chip budding was performed approximately one and a half months after rootstock planting, on 11 May 2017. Each plum variety was budded on 15 plants of each rootstock type. The buds were sealed with a regular budding tape with care not to damage the buds or limit the plant's growth function. In the following year, the plants were irrigated three times in a month from March until the end of August with a dose of $60 \mathrm{~mm}$ per month by drum irrigation machinery, weeded to maintain the area weed-free, fertilised (YaraMila ${ }^{\circledR}$ Complex $^{\text {TM }}$, YARA) and the root and stem suckers were removed.

Evaluation. During the vegetation period, the plants were measured twice taking the length of the new growth from the grafting point (31 May and 30 June). At the end of the vegetation period (30 October), total height of the plant from the grafting point was measured, and diameter of the stem above the grafting point, number of taken buds, and number of feathers were recorded. The collected data were processed in STATISTICA 10 software using a one-way and two-way ANOVA analyses, followed by a Duncan test, which divided the variants into homogenous groups.

\section{RESULTS}

Total height of the plants. Total height of the trees was measured at the end of the vegetation period on 30 October 2017. The highest value was recorded for hybrid SLE2014/1 on Torinel rootstock, for which the average total height was $68.3 \mathrm{~cm}$ (Fig. 1). The lowest total height was obtained for variety 'Stanley' on St. Julien rootstock, for which the average total height was only $5 \mathrm{~cm}$ (Table 2).

The best growth was shown by hybrid SLE2014/1, with an average total plant height $38.6 \pm 2.3 \mathrm{~cm}$, regardless of the rootstock. The worst results among varieties were recorded for variety 'Fertility' with an average total plant height of $14.3 \pm 3.4 \mathrm{~cm}$. Among the rootstocks, the best results were obtained with Torinel rootstock, having an average total plant height of $47.1 \pm 3.5 \mathrm{~cm}$, while the lowest values of total plant height were measured on St. Julien rootstock $(12.6 \pm 2.4 \mathrm{~cm})$. Significant differences were found within a group of the varieties and among the group of rootstocks. The Duncan test divided the varieties into three homogenous groups and the rootstocks into five groups (see Table 3 and Fig. 1).

The height of the plants was also recorded during the vegetation period. The first measuring date was 30 May. On that 


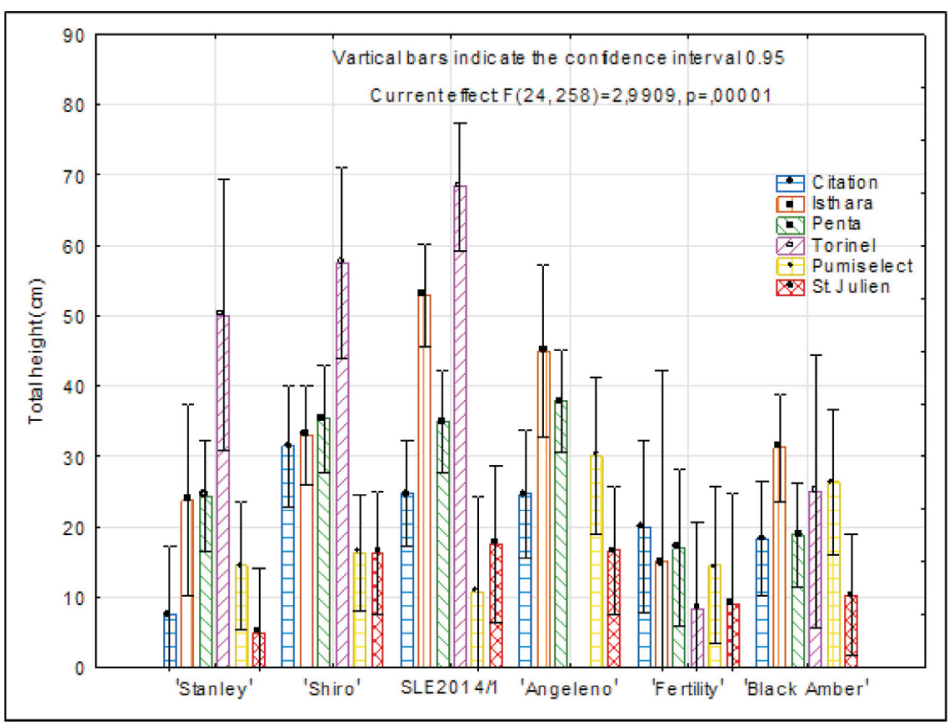

Fig. 1. Average height of the plum nursery trees.

Table 2

HEIGHT OF NURSERY TREES, MEASURED DURING VEGETATION PERIOD

\begin{tabular}{|c|c|c|c|c|c|c|}
\hline Types of rootstock & Varieties of plum & Height $31.05, \mathrm{~cm}$ & Height $30.06, \mathrm{~cm}$ & Height $30.10, \mathrm{~cm}$ & $\begin{array}{c}\text { Thickness above } \\
\text { budding, mm }\end{array}$ & $\begin{array}{c}\text { Number } \\
\text { of feathers }\end{array}$ \\
\hline \multirow[t]{6}{*}{ Citation } & Stanley & 2.7 & 6.5 & 7.6 & 4.4 & - \\
\hline & Shiro & 3.7 & 20.3 & 31.5 & 5.1 & 1.0 \\
\hline & SLE2014/1 & 4.0 & 14.3 & 24.8 & 4.4 & 2.0 \\
\hline & Angeleno & 2.3 & 14.8 & 24.7 & 4.3 & 1.8 \\
\hline & Fertility & 2.6 & 13.0 & 20.0 & 4.2 & 2.0 \\
\hline & Black Amber & 2.6 & 9.3 & 18.4 & 5.1 & - \\
\hline \multirow{6}{*}{ Ishtara } & Stanley & 1.4 & 7.0 & 23.8 & 4.0 & - \\
\hline & Shiro & 1.0 & 7.9 & 33.0 & 4.7 & 2.4 \\
\hline & SLE2014/1 & 1.4 & 14.3 & 52.9 & 5.3 & 2.4 \\
\hline & Angeleno & 0.6 & 10.4 & 45.0 & 5.8 & 6.2 \\
\hline & Fertility & 0.7 & 5.0 & 15.0 & 3.5 & 3.0 \\
\hline & Black Amber & 1.0 & 9.3 & 31.2 & 4.4 & 3.1 \\
\hline \multirow[t]{6}{*}{ Penta } & Stanley & - & 15.2 & 24.3 & 4.3 & 2.3 \\
\hline & Shiro & 0.5 & 7.6 & 35.4 & 5.2 & 4.6 \\
\hline & SLE2014/1 & 0.5 & 14.4 & 35.0 & 4.5 & 3.6 \\
\hline & Angeleno & 0.5 & 14.4 & 37.9 & 5.0 & 7.1 \\
\hline & Fertility & - & 6.9 & 17.0 & 3.0 & 4.4 \\
\hline & Black Amber & 0.6 & 9.5 & 18.9 & 4.1 & 3.5 \\
\hline \multirow{6}{*}{ Torinel } & Stanley & - & 5.7 & 50.0 & 7.5 & - \\
\hline & Shiro & - & 5.0 & 57.5 & 10.3 & 4.0 \\
\hline & SLE2014/1 & - & 12.3 & 68.3 & 9.1 & 6.6 \\
\hline & Angeleno & - & - & - & - & - \\
\hline & Fertility & - & 4.2 & 8.4 & 2.8 & 2.0 \\
\hline & Black Amber & - & 3.5 & 25.0 & 5.0 & - \\
\hline \multirow[t]{6}{*}{ Pumiselekt } & Stanley & 0.8 & 6.8 & 14.6 & 4.1 & 2.5 \\
\hline & Shiro & 0.7 & 6.3 & 16.4 & 3.5 & 2.3 \\
\hline & SLE2014/1 & 0.6 & 3.2 & 10.8 & 2.5 & - \\
\hline & Angeleno & 0.8 & 10.0 & 30.0 & 4.9 & 3.8 \\
\hline & Fertility & 0.5 & 7.0 & 14.5 & 2.8 & 3.0 \\
\hline & Black Amber & 0.7 & 8.4 & 26.4 & 4.7 & 1.8 \\
\hline \multirow[t]{6}{*}{ St. Julien } & Stanley & - & 5.6 & 5.0 & 2.8 & - \\
\hline & Shiro & - & 4.7 & 16.3 & 3.0 & 2.0 \\
\hline & SLE2014/1 & - & 4.1 & 17.5 & 3.2 & 1.7 \\
\hline & Angeleno & - & 3.7 & 16.7 & 3.0 & 1.6 \\
\hline & Fertility & - & 2.3 & 9.0 & 2.0 & - \\
\hline & Black Amber & - & 4.8 & 10.3 & 2.5 & 2.0 \\
\hline
\end{tabular}


time, Torinel and St. Julien rootstocks had not yet started sprouting, nor had 'Fertility' and 'Stanley' varieties on Penta rootstock. The highest average growth was observed for hybrid SLE2014/1 (4 cm). On the second measuring date (30 June), all varieties on all rootstocks had sprouted with the exception of 'Angeleno' variety on Torinel rootstock. The highest plant height $(20.3 \mathrm{~cm})$ was recorded for variety 'Shiro' on Citation rootstock (see Table 3 ).

Average stem diameter above budding point. Among all combinations, the largest stem diameter was recorded for variety 'Shiro' on Torinel rootstock $(10.3 \mathrm{~mm})$. The smallest stem diameter was recorded for variety 'Fertility' on St. Julien rootstock with the value being $2 \mathrm{~mm}$ (see Table 3).

On average, the largest stem diameter among the studied varieties was found for hybrid SLE 2014/1 (5.07 \pm $0.24 \mathrm{~mm}$ ). The lowest average value was recorded for variety 'Fertility' $(3.05 \pm 0.36 \mathrm{~mm})$. Among rootstocks, the varieties had the largest stem diameter on Torinel rootstock $(7.34 \pm 0.34 \mathrm{~mm})$, whereas the lowest value was recorded on Pumiselekt rootstock $(3.84 \pm 0.24 \mathrm{~mm})$. Significant differences were recorded within the group of varieties and rootstocks as well. Duncan test divided the varieties into three homogenous groups and the rootstocks into four groups (see Table 3).

Number of feathers. The highest number of feathers was recorded on 'Angeleno' variety on Penta rootstock (7.1 pcs). No feathers were recorded on: varieties 'Fertility' and 'Stanley' on St. Julien rootstock; variety SLE2014/1 on Pumiselekt rootstock; varieties 'Angeleno', 'Black Amber' and 'Stanley' on Torinel rootstock; variety 'Stanley' on Ishtara rootstock; and varieties 'Stanley' and 'Black Amber' on Citation rootstock (see Table 3).

Among varieties, the highest number of feathers was recorded on variety 'Angeleno' ( $4.48 \pm 0.46 \mathrm{pcs})$, whereas the lowest was on variety 'Stanley' (2.25 \pm 0.98 pcs). Among rootstocks, the best branching results were exhibited by varieties on Torinel rootstock (average $5.00 \pm 0.67$ feathers). The weakest branching was recorded for varieties on Citation rootstock with the average number of $1.75 \pm 0.65$ feathers. Significant differences were recorded within the group of varieties and rootstocks. The Duncan test divided the varieties into two homogenous groups and rootstocks into three groups (see Table 3).

Bud take. The highest bud take was recorded for 'Shiro' on Ishtara rootstock, for which $100 \%$ of buds grew successfully. 'Angeleno' on Torinel rootstock had the lowest bud take with no buds growing (Table 3).

The variety with the best bud take was 'Shiro' with $70.0 \%$ of all budded buds growing. The lowest bud take, on the other hand, was recorded for variety 'Fertility' with only $28.9 \%$ of all budded buds growing. Among rootstocks, the highest number of growing buds was recorded on Penta rootstock $(81.1 \%)$, whereas the lowest number was recorded
Table 3

FINAL VALUES FOR THE STUDIED CHARACTERISTICS (TOTAL HEIGHT, STEM THICKNESS ABOVE BUDDING POINT, NUMBER OF FEATHERS AND BUD TAKE) EVALUATED AT THE END OF VEGETATION PERIOD

\begin{tabular}{|c|c|c|c|c|}
\hline $\begin{array}{l}\text { Varieties of } \\
\text { plum }\end{array}$ & $\begin{array}{l}\text { Total height } \\
\quad(\mathrm{cm})\end{array}$ & $\begin{array}{c}\text { Thickness } \\
\begin{array}{c}\text { above budding } \\
\text { (mm) }\end{array}\end{array}$ & $\begin{array}{l}\text { Number of } \\
\text { feathers }\end{array}$ & $\begin{array}{c}\text { Bud take } \\
(\%)\end{array}$ \\
\hline Stanley & $16.45 \pm 2.64^{\mathrm{a}}$ & $4.08 \pm 0.28^{\mathrm{a}}$ & $2.25 \pm 0.98^{\mathrm{a}}$ & 48.9 \\
\hline Shiro & $29.25 \pm 2.21^{\mathrm{b}}$ & $4.73 \pm 0.23^{\mathrm{ab}}$ & $3.02 \pm 0.42^{\mathrm{ab}}$ & 70.0 \\
\hline Angeleno & $30.39 \pm 2.26^{\mathrm{b}}$ & $4.52 \pm 0.28^{\mathrm{ab}}$ & $4.48 \pm 0.46^{\mathrm{b}}$ & 47.8 \\
\hline Fertility & $14.34 \pm 3.44^{\mathrm{a}}$ & $3.05 \pm 0.36^{\mathrm{c}}$ & $3.06 \pm 0.69^{\mathrm{ab}}$ & 28.9 \\
\hline Black Amber & $21.22 \pm 2.32^{\mathrm{a}}$ & $4.18 \pm 0.25^{\mathrm{a}}$ & $2.96 \pm 0.55^{\mathrm{ab}}$ & 63.3 \\
\hline$\underline{\text { SLE2014/1 }}$ & $38.58 \pm 2.26^{\mathrm{c}}$ & $5.07 \pm 0.24^{\mathrm{b}}$ & $3.70 \pm 0.5^{\mathrm{ab}}$ & 66.7 \\
\hline $\begin{array}{l}\text { Types of } \\
\text { rootstock }\end{array}$ & $\begin{array}{l}\text { Total height } \\
\quad(\mathrm{cm})\end{array}$ & $\begin{array}{c}\text { Thickness } \\
\begin{array}{c}\text { above budding } \\
\text { (mm) }\end{array}\end{array}$ & $\begin{array}{l}\text { Number of } \\
\text { feathers }\end{array}$ & $\begin{array}{c}\text { Bud take } \\
(\%)\end{array}$ \\
\hline Citation & $21.82 \pm 2.21^{b}$ & $4.62 \pm 0.22^{\mathrm{a}}$ & $1.75 \pm 0.65^{\mathrm{a}}$ & 62.20 \\
\hline Ishtara & $38.00 \pm 2.29^{\mathrm{d}}$ & $4.82 \pm 0.22^{\mathrm{a}}$ & $3.05 \pm 0.42^{\mathrm{ab}}$ & 57.80 \\
\hline Penta & $29.28 \pm 1.94^{\mathrm{c}}$ & $4.48 \pm 0.19^{\mathrm{ab}}$ & $4.45 \pm 0.34^{b c}$ & 81.10 \\
\hline Torinel & $47.13 \pm 3.53^{\mathrm{e}}$ & $7.34 \pm 0.34^{\mathrm{d}}$ & $5.00 \pm 0.67^{\mathrm{c}}$ & 24.40 \\
\hline Pumiselekt & $18.74 \pm 2.52^{\mathrm{ab}}$ & $3.84 \pm 0.24^{\mathrm{b}}$ & $2.62 \pm 0.53^{\mathrm{a}}$ & 47.80 \\
\hline St. Julien & $12.61 \pm 2.41^{\mathrm{a}}$ & $2.79 \pm 0.23^{c}$ & $1.76 \pm 0.72^{\mathrm{a}}$ & 52.20 \\
\hline
\end{tabular}

on Torinel rootstock with only $24.4 \%$ buds growing (see Table 3 and Fig. 2).

\section{DISCUSSION}

One of the ways to increase nursery production process efficiency is to shorten the growing time to a minimum, i.e. one year. Such methods are already in use in locations like Oregon and California (USA) and Italy (Anonymous, 2018), however these locations have different climatic conditions than the Czech Republic.

The plants grown on Torinel rootstock reached the highest total height $(47.13 \pm 3.53 \mathrm{~cm})$, however only $24.4 \%$ of the buds grew successfully on this rootstock. Torinel is a rootstock with moderate vigour (Audergon et al., 1991), which can explain the vigorous growth of budded trees as compared to the other rootstocks. Admittedly, very low growth was recorded on St. Julien 'Wädenswil', a moderate vigour rootstock (Dēkena et al., 2013), yet this rootstock has been exhibiting very poor growth qualities in the location of Lednice for a longer period of time. The lowest growth (18.74 \pm $2.52 \mathrm{~cm})$ and related low stem diameter $(3.84 \pm 0.24 \mathrm{~cm})$ were found on Pumiselekt rootstock (Jacob, 1999; Gudarowska et al., 2006). The poor results for this rootstock can probably be attributed to the dwarfing characteristics of this rootstock.

Branching of the nursery trees in a nursery is very important. Fruit growers as well as gardeners demand plants with adequate lateral shoots of good quality, i.e. feathers of sufficient length and diameter (Sazo et al., 2011). European type plums, apart from some varieties, produce sufficient quan- 


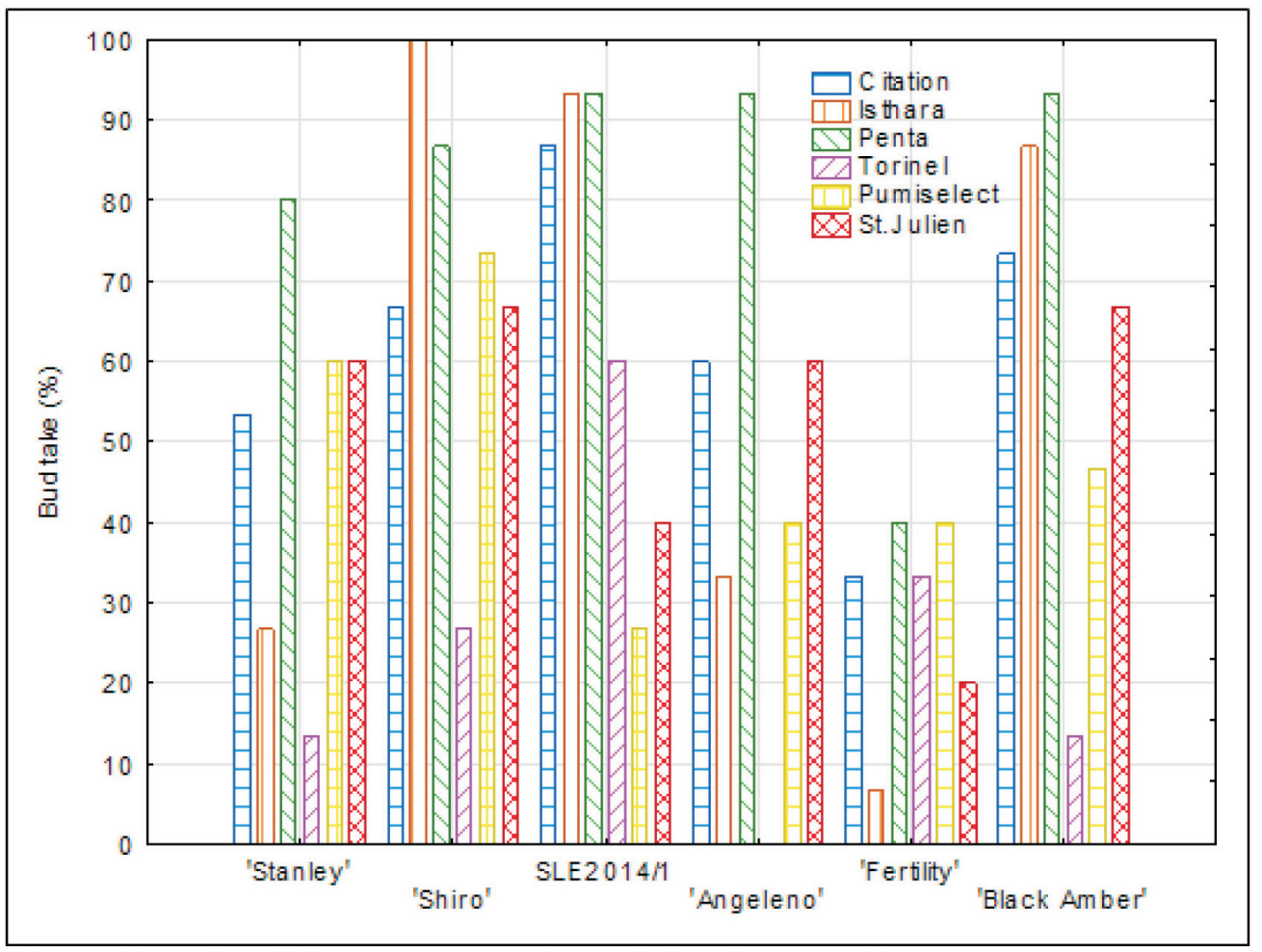

Fig. 2. Bud take of the varieties on the individual rootstocks.

tity of good quality lateral branches (Magyar and Hrotko, 2002). For the purpose of the study, only one European plum variety, 'Stanley', was used. Although this variety branches relatively well in nurseries (Wolf et al., 2018), in this study 'Stanley' produced lateral shoots only on Pumiselekt (2.5 feathers) and Penta (2.3 feathers) rootstocks and were of a very poor quality. The poor quality branching of variety 'Stanley' could be associated with the poor growth of this variety, which reached an average height of only $16.45 \pm 2.64 \mathrm{~cm}$. This finding leads to the conclusion that variety 'Stanley' is probably not suitable for spring budding. Asian plum varieties branch very well in nurseries. The best results of branching were achieved with 'Angeleno' variety on Penta rootstock, having 7.1 feathers on average. Penta is a vigorous rootstock (Nicotra and Moser, 1996). Vigorous and moderately vigorous rootstocks seem to be the best choice for spring budding as they can reach higher quality nursery trees. Moreover, 'Angeleno', a vigorous variety, was evaluated in the nursery as the best branching variety in this experiment $(4.48 \pm 0.46$ feathers $)$.

Bud take is the most important characteristic, as each unsuccessful bud causes loss for the nursery. The most successful appeared to be variety 'Shiro' (Asian type variety with vigorous growth), which exhibited $70 \%$ of bud take in general and $100 \%$ of bud take on Ishtara rootstock. The most successful rootstock was Penta, a vigorous rootstock, with $81.1 \%$ of bud take. The lowest bud take was recorded for 'Fertility' variety (28.9\%). The poor result was probably caused by very poor affinity of some of the selected rootstocks in the experiment, as 'Fertility' is an interspecific hybrid probably had with this variety.

As Figure 1 shows, varieties 'Shiro', 'Stanley' and SLE2014/1 had the best growth (total height above $50 \mathrm{~cm}$ ) on Torinel rootstock, yet their bud take was very low (below 30\%), with the exception of variety SLE2014/1 (60\%). The low bud take could have possibly been a result of a later sprouting time of Torinel rootstock compared to the other rootstocks, which could have caused damage to the grafted buds. Figure 1 shows that varieties 'Angeleno' and SLE2014/1 achieved good growth (total heights above $40 \mathrm{~cm}$ ) on Ishtara rootstock. Admittedly, bud take of variety 'Angeleno' was only $33.0 \%$, yet bud take of hybrid SLE2014/1 was 93.3\%. Ishtara rootstock could consequently be a very suitable rootstock for hybrid SLE2014/1 in the case of spring budding.

Spring budded buds start to sprout later and their growth is not as efficient in the period of the first intensive growth compared to the summer budded buds, however, they catch up the delay during summer in the period of the second intensive growth (Anonymous, 2018). However, in the conditions of the Czech Republic, vegetation period is not long enough as the period of the second intensive growth is very short. Therefore, the technology of nursery tree production in one year requires adequate optimisation, selection of suitable varieties and rootstocks and, particularly, determination of the appropriate date for the budding.

\section{CONCLUSION}

The preliminary results show that method of spring budding to produce nursery trees within one year is not as suitable in the conditions of the middle Europe as in southern countries with a longer vegetation period. However, by following the bellow mentioned rules, this method could be successful: 
- rootstocks must have a sufficient root system and their sprouting must not be delayed; autumn planting of the rootstock should be preferred;

- rootstocks with moderate/vigorous growth should be used (Penta, Ishtara);

- varieties with moderate/vigorous growth should be used ('Angeleno', 'Shiro', SLE2014/1).

\section{ACKNOWLEDGEMENTS}

This research was funded by NAZV/KUS project No QJ1510081 by the Ministry of Agriculture of the Czech Republic.

\section{REFERENCES}

Anonymus, (2018). Techniques of Budding. Available at: https://aggie-horticulture.tamu.edu/faculty/davies/pdf\% 20 stuff/ ph\%20final\%20galley/M13_DAVI4493_08_SE_C13.pdf (accessed 03.04.2019)

Audergon, J. M., Duquesne, J., Nicolas J. C., Audubert, A. (1991). A new selected plum rootstock for apricot varieties: Torinel ${ }^{\circledR}$. Acta Horticult., 293, 395-400.

Buchtová, I. (2017). Situational and outlook report of fruits. Ministry of Agriculture in Czech Republic, Prague, pp. 60 (in Czech). Available from: http://eagri.cz/public/web/file/569075/SVZ_Ovoce_12_2017.pdf (accessed 03.05.2019)

Dēḳena, D., Jänes, H., Poukh, A. V., Alsiṇa, I. (2013). Influence of rootstock on plum flowering intensity in different growing regions. Proc. Latvian Acad. Sci. Section B, 67 (2), 207-210

Received 28 January 2019

Accepted in the final form 24 March 2019
Gudarowska, E., Licznar-Małańczuk, M. (2006). The quality of root system of dwarf rootstock 'Pumiselect' for peach trees. Agronomijas Vestis, 9, 24-27.

Howard, B. H. (1977). Chip-budding fruit and ornamental trees. Proc. Inter. Plant Prop. Soc., 27, 357-365.

Jacob, H. (1999). Applied fruit breeding of the Geisenheim Research Institute. Erwerbsobstbau (Germany), 41 (5), 169-173.

Kidd, E. L. (1987). Asexual propagation of fruit and nut trees at Stark Brothers Nurseries. Comb. Proc. Intl. Plant Prop. Soc., 36, 427-30.

Kozderová, V. (2017). Situational and outlook report of flowers and ornamental plants. Ministry of Agriculture in Czech Republic, Prague, pp. 49 (in Czech). Available from: http://eagri.cz/public/web/file/580008/SVZ_Kvetiny_12_2017.pdf (accessed 03.05.2019).

Kumar, G. N. M. (2011). Propagation of Plants by Grafting and Budding. Washington State University. Available at: https://www.growables.org/information/documents/PlantPropagationGraftingBuddin.pdf (accessed 03.04.2019)

Nicotra, A., Moser, L. (1996). Two new plum rootstocks for peach and nectarines: Penta and Tetra. In VI International Symposium on Integrated Canopy, Rootstock. Environ. Physiol. Orchard Syste., 451, 269-272.

Okie, W. R., Ramming, D. W. (1990). Plum breeding worldwide. HortTechnology, 9 (2), 162-176.

Osborne, R. H. (1987). Chip budding techniques in the nursery. Comb. Proc. Intl. Plant Prop. Soc., 36, 550-555.

Sazo, M. M., Robinson, T. L. (2001). The use of plant growth regulators for branching of nursery trees in NY State. New York Fruit Quartely, 19 (2), 5-9.

Tubesing, C. E. (1988). Chip budding of magnolias. Comb. Proc. Intl. Plant Prop. Soc. 87, 377-379.

Wolf, J., Venuta, R., Ondrášek, I., Nečas, T. (2018). Use of plant growth regulators in fruit nursery production of plums and sweet cherries. Acta Horticult., 1206, 299-307.

\section{PAVASARA POTĒŠANAS TEHNOLOĢIJAS IESPĒJAMĀ IZMANTOŠANA PLŪMJU STĀDU RAŽOŠANAI}

Galvenais šì darba mērḳis bija pārbaudīt iespēju saīsināt plūmju stādu izaudzēšanas laiku kokaudzētavās, lai paaugstinātu kokaudzētavu ražošanas ekonomisko rentabilitāti. Lai sasniegtu šo mērķi, pavasarī uz potcelmiem Citation ${ }^{\circledR}$, Ishtara ${ }^{\circledR}$, Penta ${ }^{\circledR}$, Torinel ${ }^{\circledR}$, Pumiselekt and St. Julien (no Vēdensvilas) tika uzpotētas šķirnes ‘Shiro', 'Angeleno o ${ }^{\circledR}$, 'Black Amber', SLE2014/1, 'Fertility' (diploīdās plūmes) un 'Stanley' (mājas plūme) kā kontrole. Veǵgetācijas perioda beigās katram stādam tika noteikts garums (no potes vietas), stumbra resnums virs potes vietas un dzinumu skaits. Kā labākais potcelms tika atzīts Penta ${ }^{\circledR}$, kā piemērotākā škirne — 'Shiro'. Kā labākā škirnes/potcelma kombinācija konstatēta 'Shiro' uz potcelma Ishtara ${ }^{\circledR}$, kurā $100 \%$ potēto koku sasniedza vidēji $33,0 \pm 3,6 \mathrm{~cm}$ augstumu. Visgarākie koki vidēji $68,3 \pm 4,6 \mathrm{~cm}$ tika konstatêti kombinācijā SLE2014/1 uz potcelma Torinel ${ }^{\circledR}$. 